This item was submitted to Loughborough's Research Repository by the author.

Items in Figshare are protected by copyright, with all rights reserved, unless otherwise indicated.

\title{
CSR disclosure in response to major airline accidents: a legitimacy-based exploration
}

\section{PLEASE CITE THE PUBLISHED VERSION}

http://dx.doi.org/10.1108/SAMPJ-12-2014-0080

\section{PUBLISHER}

(C) Emerald Group Publishing Limited

\section{VERSION}

AM (Accepted Manuscript)

\section{PUBLISHER STATEMENT}

This work is made available according to the conditions of the Creative Commons Attribution-NonCommercialNoDerivatives 4.0 International (CC BY-NC-ND 4.0) licence. Full details of this licence are available at: https://creativecommons.org/licenses/by-nc-nd/4.0/

\section{LICENCE}

CC BY-NC-ND 4.0

\section{REPOSITORY RECORD}

Vourvachis, Petros, Therese Woodward, David G. Woodward, and Dennis M. Patten. 2019. "CSR Disclosure in Response to Major Airline Accidents: A Legitimacy-based Exploration”. figshare. https://hdl.handle.net/2134/19629. 


\title{
CSR Disclosure in Response to Major Airline Accidents: A Legitimacy-Based Exploration
}

\begin{abstract}
Purpose - This paper contributes to the literature investigating disclosure reactions to legitimacy threats by analysing the corporate social responsibility disclosure reactions to catastrophic accidents suffered by major airlines.

Design/methodology/approach - We use content analysis to examine changes in annual report disclosure in response to four separate airline disasters. We adopt two classification schemes and two measurement approaches to explore these changes. Findings - We find that for three events the organisations appear to have responded with considerable increases in CSR disclosure that are consistent with attempts of legitimation. For one of the events examined we find no disclosure response and suggest that this could be due to the company’s unwillingness to accept responsibility.

Research limitations/implications - The study's focus on major airlines that have suffered an accident with available annual reports in English meant that other companies and more recent events had to be excluded from the analysis.

Practical implications - The findings demonstrate the use of the annual report as a legitimation tool and further highlight the need for greater transparency and comparability across publications.

Originality/value - The paper adds to the scarce literature examining corporate disclosure reactions following threats to their social legitimacy.
\end{abstract}

Keywords: aviation accidents, content analysis, CSR disclosure, legitimacy theory. 


\section{Introduction}

A number of studies over the past quarter-century investigate corporations' disclosure response to catastrophic events. Almost universally couched in legitimacy theory arguments that the disasters increase the social and political exposures of the companies (or their industries), the examinations consistently document that firms respond to the legitimacy threats with increased social and/or environmental disclosure in their annual reports. Almost all of the prior studies focus on events that are largely environmental in nature, and they tend to limit their analyses to changes in environmental disclosure. In this study, we extend this body of research by examining whether a different type of catastrophic event - airline crashes with major loss of life - similarly induce disclosure reactions, and we look for this across a broader spectrum of social disclosures.

We examine changes in annual report corporate social responsibility (CSR) disclosures in response to four separate airline disasters occurring in the $21^{\text {st }}$ century Air France Flight 4590 (the Concorde crash) and Singapore Airlines Flight 006, both in 2000, Scandinavian Airlines Flight 686 in 2001, and Air France Flight 447 in 2009. ${ }^{1}$ In each case, the accident resulted in significant casualties and, we argue, led to potential threats to the parent companies with respect to their social legitimacy. Our analysis of the annual reports reveals that, for the first three events, the firms appear to have responded with changes in CSR disclosure that are consistent with attempts at legitimation. We show that CSR disclosure in total (in terms of pages of information provided) increased substantially in each case, as did the amount of space allocated to

\footnotetext{
${ }^{1}$ We note that 2014 saw several high profile airline disasters including the mysterious loss of Malaysia Airlines Flight 370 over the Indian Ocean, the shooting down of Malaysia Airlines Flight 17 over the Ukraine, and the crash of AirAsia Flight 8501 in Indonesia. The recency of these events precludes us from including them in our analysis.
} 
disclosures classified as positive in nature and more specifically, disclosures related to companies' health and safety practices. We document that these changes are quite different from disclosure changes preceding the airline disasters. Interestingly, we also show that the increases in CSR disclosure are far more extensive than the amount of space actually devoted to discussions of the accidents themselves.

In contrast to the catastrophic events of the early 2000s, we fail to find similar responses with respect to Air France’s disclosures following the 2009 crash of Flight 447. The annual report space allocated to both total and positive-themed CSR disclosures declined relative to the prior year, and while health and safety disclosure space increased slightly, it was smaller than the corresponding increase in the prior period. One potential explanation for this differing response is that Air France might instead have used its standalone sustainability report for a response in this latter period (Air France was not issuing standalone reports at the time of its 2000 accident). However, a review of these reports finds similar patterns of CSR disclosure change as those in the annual reports. And while the global financial crisis may have played a role in the decreased emphasis on CSR information provision, we examined changes in disclosure across the two years for a sample of nine other European airlines and find that, on average, CSR disclosure actually increased slightly. As such, we suggest the differing response may be a function of the longer-term investigation of the causes of this particular accident and Air France's unwillingness to accept responsibility for the crash until the issuance of the formal investigative report almost three years later.

In general, our study provides additional insight into corporate use of CSR disclosure as a legitimation tool. The paper proceeds as follows. The next section provides 
background for our study and lays out our expectations. This is followed by a discussion of our research methods. The penultimate section of the paper presents the results of our analyses, and the paper concludes with a discussion of the findings.

\section{Background}

Drawing from the foundational work of Parsons (1960) and Weber (1978), legitimacy theory is centred on the notion of a social contract, whereby "business agrees to perform various socially desired actions in return for approval of its objectives, other rewards and ultimate survival” (Guthrie \& Parker, 1989, p. 344). Proponents of its use in disclosure research argue that a corporation can attempt to legitimate itself in the eyes of the public by voluntarily disclosing information about its social and environmental activities. A number of studies discuss specific legitimation strategies (e.g. Perrow, 1970; Dowling \& Pfeffer, 1975; Savage et al., 2000), but Lindblom’s (1993) delineation of options perhaps best illuminates this potential role of disclosure. Lindblom argues companies can respond to perceived legitimacy threats by:

1. Bridging the output, methods, and goals into conformity with popular views of what is appropriate, thus making "internal adjustments to close the legitimacy gap” (Lindblom, 1993, p. 13).

2. Making no internal adjustments but, rather, attempting to change perceptions, by demonstrating "the appropriateness of the output, methods, and goals to the public through education and information" (p. 14).

3. Distract attention away from the issue of concern: "Identifying organizational output, methods, and goals with the popular perception of what is appropriate without any attempt at actual conformity" (p. 15).

4. Seek an adjustment in societal expectations, by directing disclosure "toward bridging the relevant publics' expectations in line with corporate output, methods, or goals” (p. 16).

In each of the last three cases, firms rely on disclosure in an attempt to reduce their exposures to potential social and political costs. Thus, Cho and Patten (2007), 
specifically noting the voluntary nature of the activity, refer to the disclosure as a tool of legitimation in that it is used not to provide transparent accountability for social and environmental performance, but instead to enhance the image of the firm.

Several studies within the CSR arena document disclosure changes in response to legitimacy threats arising from catastrophic events. Both indirect and direct exposure settings have been investigated. Patten (1992) and Walden and Schwartz (1997) examined the effects of the Exxon Valdez oil spill on environmental disclosure in the annual reports of related, but not directly involved, American corporations and found that the levels of environmental disclosure increased significantly in the year following the accident. Likewise, Coetzee \& van Staden (2011) found that the entire South African mining industry evidenced an increase in disclosure levels following two major mining accidents. On the other hand, Deegan \& Rankin (1996), Deegan et al. (2000), Woodward et al. (2008), Cho (2009), and de Villiers \& van Staden (2011) all examined the reactions of companies directly exposed to legitimacy threats, and all document evidence of changing disclosure. The findings of all these studies lend support to the argument that corporations seek to address a legitimacy threat by increasing disclosure, but almost all of them focus on events largely related to environmental exposures, and as such tend to examine primarily environmental information provision.

In this study, we extend prior research by analysing the CSR disclosure reactions to catastrophic accidents suffered by major airlines. Accidents can generally be defined as "discrete one-time undesirable or unfortunate events that happen unexpectedly in the life of a corporation and cause damage to any number or kind of stakeholders” (Zyglidopoulos, 2001, p. 420). In a world characterised by "the instant and photographic 
reporting of calamity” (p. 421) some accidents receive such extensive media coverage that they become landmarks in the history of a company, and such is the case with catastrophic aeroplane crashes over the years. Bailey (2004), for example, notes that a number of major airlines, including Pan American, at one time the de facto flag-carrier of the United States, "have failed to recover from prolonged periods of crisis which were either precipitated, or worsened, by a badly-managed response to an aircraft accident.” According to Knight \& Perry (1996), aviation disasters have resulted in a considerable negative impact on shareholder value as well as reduced credit ratings. Indeed, Grossman (2005) further states that the negative impact of accidents is so significant that most airlines even retire the flight number after a crash, and Bailey (2004) asserts that some smaller aviation companies have been forced into bankruptcy or to change their brand name following major crashes. We thus argue that aviation accidents likely lead to a major legitimacy threat for companies involved and offer an opportunity to extend the limited research into impacts of catastrophic events outside of the environmental domain (Coetzee \& van Staden, 2011). For our investigation, we limit the analysis to major crashes occurring in the $21^{\text {st }}$ century, and we briefly describe each of these events in the methods section below.

Each of the disasters examined in this study resulted in substantial loss of life, received extensive media coverage, and, we argue, potentially introduced new social exposures for the airline companies involved. Faced with a potential threat to their social legitimacy, the firms thus had an incentive to respond with increased CSR disclosure. Accordingly, the primary intent of our investigation is to identify how annual report CSR disclosures changed for each of the companies in the year following the relevant aviation 
disaster. Based on the prior studies of corporate CSR responses to other types of catastrophic events, we anticipate increased CSR disclosure in general. However, given that prior studies indicate that firms seeking legitimacy tend to focus on providing information that portrays the companies in a positive light (see, e.g., Slack \& Shrives, 2008; Aerts \& Cormier, 2009; Kotonen, 2009; Islam \& Deegan, 2010; Mahadeo et al., 2011; Sen et al., 2011), we also anticipate that the increases will be more substantial in terms of positive, as opposed to negative disclosures. Finally, the prior studies of changes in CSR disclosure in response to catastrophic events indicate changes in environmental exposures drive changes in environmental disclosure. Since airline accidents relate more closely to health and safety issues, we also anticipate that, if the changes are driven by legitimacy concerns, airline firms will respond to the events with increases in disclosure in this specific area of CSR disclosure.

\section{Methods}

\subsection{Events examined}

\subsubsection{Air France Flight 4590 (the Concorde) crash}

The Concorde was the 'flagship' aircraft for both Air France and British Airways, an "emblem like no other of the power of technology" (Bunting, 2000). Following its departure from Paris’ Charles de Gaulle Airport on 25 July 2000, Air France Flight 4590, a non-scheduled service to New York City, crashed and burned 10 miles (15km) northeast of Paris. After nearly a quarter of a century of providing the world's only sustained supersonic passenger service, the Concorde suffered its first fatal accident (Gero, 2006). All 109 persons aboard, including the nine members of its crew, plus four others on the ground, perished in the disaster, and an additional 6 persons suffered injuries. The accident attracted an enormous amount of negative publicity, making it the 
most famous air-crash in aviation industry (other than the September $11^{\text {th }}$ attacks - Gero, 2006). As a consequence, both the French and the British civil aviation authorities revoked Concorde's certificate of airworthiness. Although some modifications were made and Concorde re-entered regular service in November 2001, in the spring of 2003 its only two operators announced that due to low passenger loads, high maintenance costs and the general slowdown in the airline industry, they would terminate its service by the end of the year, withdrawing from use the rest of the aircraft (Gero, 2006).

\subsubsection{SIA Flight 006 crash}

SIA had its first fatal accident and reportedly "experienced its darkest hour” (SIA, 2001AR, p. 6) on $31^{\text {st }}$ October 2000. Designated as Flight 006, the wide-bodied Boeing 747 SIA jetliner crashed during taking off at the T’ai-pei International Airport in Taiwan. The disaster resulted in the death of 83 of the 179 persons aboard the aircraft, including four cabin attendants. Among the survivors, 57 passengers and 13 crew members suffered injuries and 25 other persons escaped unscathed - the latter including two of the three flight crewmen (Gero, 2006). Not only did the accident spoil the company's prior record of zero fatalities, it also generated a lot of negative publicity over SIA's “catalogue of failings” (Perrin, 2000). At the centre of the public criticism was the pilot's inexplicable decision to use the wrong runway and to proceed with taking off despite severe weather conditions (Gero, 2006). Survivors of the crash also stated that the members of staff were unable to help the passengers escape from the aircraft due to being frozen by fear and/or due to lack of competence in emergency procedures, with some flight attendants “failing to help passengers open emergency doors, fleeing the plane before all inside had been rescued” (Perrin, 2000). These failings led hundreds of 
survivors and relatives of those who perished to file lawsuits against the airline (SIA, 2001AR) and the company subsequently dismissed the pilot and a co-pilot of that flight. The accident appeared to have an impact on SIA's share price, which (after reaching a peak in October) in six months lost almost $30 \%$ of its market value despite the concurrent increase in turnover (SIA, 2001AR).

\subsubsection{SAS Flight SK686 crash}

SAS experienced its first fatal accident on 8 October 2001. SAS Flight SK686, an MD-87 plane carrying 110 people and heading to Copenhagen, Denmark, collided with a Cessna at Milan's Linate airport. The plane had just received clearance for take-off from the air traffic control tower when the Cessna taxied towards the runway. The SAS MD87 collided with the Cessna and slid sideways into an airport building. A total of 118 people died, comprising all 110 people (104 passengers and 6 staff) on board the SAS flight. Four people died in the Cessna, and four people who worked in the airport building also lost their lives (SAS, 2001AR). To a world still reeling from September $11^{\text {th }}$, the fiery collision of the two planes at Milan's airport looked at first like a terrorist attack, particularly since it occurred the day after the US invasion of Afghanistan. This possibility was, however, ruled out by the investigations that followed (Gero, 2006). The airport's director and air-traffic controller were among those found guilty for the disaster by an Italian court and were sentenced to spend from 6 to 8 years in prison. The airline was exonerated of any responsibility. However, considering that this was Italy's worst aviation disaster and the company's first fatal accident, it attracted a lot of publicity and according to SAS's 2001 annual report this was reflected in a 10\% decrease in the company's share price in the first week after the accident. 


\subsubsection{AF Flight 447 crash}

Almost nine years after the Concorde crash, Air France (which had, in the interim, merged with KLM) suffered a second plane aviation disaster. Flight 447 was a scheduled commercial flight from Rio de Janeiro to Paris, and on 1 June 2009, the Airbus A330-203 airliner used on the flight crashed into the Atlantic Ocean killing all 216 passengers and 12 aircrew. The accident was the deadliest in the history of the company and "one of the world's worst aviation disasters" and led to "the biggest crash inquiry since Lockerbie” (Ross \& Tweedie, 2012). Authorities managed to locate the wreckage and retrieve the aircraft's black boxes from the ocean floor only in May 2011. The final report, released three years after the crash, stated that the reasons for the flight's demise were temporary inconsistencies between the airspeed measurements coupled with incorrect reactions from the crew. Prior to the issuance of this report, AF had refused to take any responsibility for the accident, instead calling for more thorough investigations in order to allow the company "to reconstruct precisely what happened on the flight and determine the causes of the accident” (AF, 2011CSR, p. 9).

\subsection{CSR disclosure measure}

We examine event companies' annual reports for CSR disclosures across a threeyear window including the reports for the two years preceding each accident (designated as Y-2 and Y-1) and the year of the disaster itself (Y1). We developed our disclosure scale based on a review of prior investigations of annual report CSR disclosure (e.g., Ernst \& Ernst, 1978; Gray et al., 1995: Deegan et al., 2000: 2002), Global Reporting Initiative reporting guidelines (GRI, 2002; 2006), and assessments of information being provided in our sample company reports. The major themes consistently emerging from 
these reviews included disclosures related to marketplace (consumers, creditors), workplace (employees), community, and environment, and we compiled a listing of relevant categories of information within each. ${ }^{2}$ However, given the specific focus of our investigation, we separately classify health and safety disclosure as its own category. ${ }^{3}$ Consequently, information was considered to be CSR in nature if it related to any one of the content areas identified in Appendix A. Consistent with, for example, Patten (1992), Gray et al. (1995), Unerman (2000) and O’Dwyer (2003), we measure disclosure in pages to the hundredth of a page and include space related to both narrative and pictorial presentations (see Hackston and Milne, 1996). ${ }^{4}$ For narrative disclosure, we measured pages in terms of the percentage of lines of print on the page, ${ }^{5}$ while pages of non-narrative disclosure (pictures, graphs, etc.) were calculated using a page-adjusted grid. ${ }^{6}$ For analysis related to sub-components of the disclosure, we follow Deegan et al. (2000; 2002) and classify disclosure as positive (negative) when it refers to information about CSR activities that have a positive or beneficial (negative or detrimental) impact on nature or society. Finally, the health and safety disclosure items are identified in Appendix A. For our sub-component analysis,

\footnotetext{
${ }^{2}$ Following, for example, Gray et al. (1995), we also considered a separate category for 'other' disclosures. However, we found these to be virtually non-existent in our sample company documents and hence do not include this category in our presentation.

${ }^{3}$ Health and safety disclosures are often included as sub-components within the consumer, workplace, and/or environment classifications.

${ }^{4}$ Pesci and Costa (2014) have recently demonstrated the importance of considering pictorial disclosure in the form of images, graphs and tables in content analysis studies. For the purposes of our analysis, the general trends we report below for total disclosure held, in general, when only narrative disclosure space was considered.

${ }^{5}$ For example, if a page contained only narrative disclosure and 32 of 50 lines of print related to CSR themes, we assigned a page count of 0.64 pages.

${ }^{6}$ We also calculated CSR disclosure as the percentage of total space within each respective annual report. Disclosure patterns using this alternative measure were similar to those reported below for the page count metric and we do not include these in the presentation of results.
} 
we identify the pages of CSR disclosure that are considered positive, negative, and health and safety-related, respectively. ${ }^{7}$

\section{Results}

\subsection{Total disclosure}

Table 1 summarizes the extent of annual report disclosure for each of the four incidents examined in our study. In addition to data on CSR disclosures, the table also identifies the amount of space allocated to discussions of the accidents. If the airline companies perceive the accidents as increasing threats to the firms' social legitimacy, we expect them to respond with increased CSR disclosure. As noted in the table, the airline companies were fairly consistent with respect to the amount of coverage of the disasters, with space allocations ranging from 0.17 pages (AF Flight 447) to 0.46 pages (SAS Flight 686). Interestingly, with the exception of the last accident (AF Flight 447), the companies exhibited substantially larger increases in the space devoted to CSR disclosures (relative to year Y-1) than the amount of accident coverage itself. Air France increased CSR disclosure by 4.11 pages following the AF Flight 4590 accident, while the annual reports of Singapore Airlines and Scandinavian Airlines included increases in CSR disclosure of 5.92 and 13.79 pages, respectively. A review of the CSR disclosure levels (and changes) for the years prior to the accidents highlights the unusual nature of the disclosure changes in response to the catastrophic events. However, in contrast to the consistent patterns documented for the first three incidents, Air France's annual report CSR disclosure following the Flight 447 crash actually decreased slightly. Thus, with the

\footnotetext{
${ }^{7}$ Reliability tests were conducted to ascertain consistency and replicability for the coding procedures. These included two stability tests (Pearson's correlation coefficient and Cronbach's Alpha) and five reproducibility tests (percent agreement; Scott’s Pi; Cohen’s Kappa; Fleiss’ Kappa; and Krippendorff's Alpha). All tests were, on average, above the .90 level and met reliability standards (Lombard et al., 2002).
} 
exception of the final event, results support the argument that the airline companies appear to be using CSR disclosures to respond to potential legitimacy threats.

Table 1 about here

\subsection{Positive versus Negative Disclosure}

In Table 2 we summarize CSR disclosures based on the nature of the information being presented, where disclosures of positive-themed data is presumed to reflect attempts at legitimation. Panel A of the table presents measures of positive-themed disclosures, whereas the extent of negative CSR information provision is identified in Panel B. A review of Table 2 indicates a marked difference in changes across the two categories of information. As highlighted in Panel A, again with the exception of disclosure following AF Flight 447, the affected companies showed substantial increases in the provision of positive-themed CSR information. The increases ranged from 5.34 pages to 6.85 pages, and in each case the change is dramatically higher than the difference in disclosure from year Y-2 to year Y-1. In contrast, while each of the firms' annual reports also showed increases in the space allocated to negative-themed CSR disclosure (see Panel B of Table 2), the increases are far less dramatic than for the changes in positive disclosure. Once again, however, the disclosure response to AF Flight 447 stands in contrast to the other events. Air France’s positive CSR disclosures went down by over five pages following the accident while negative disclosure space increased by almost a page. Consistent with the results with respect to total CSR disclosure, the findings regarding changes in positive-themed information provision, excepting the AF Flight 447 response, appear to support a legitimation argument. 


\subsection{Health and Safety Disclosures}

Our third element of analysis centres on changes in space allocated to health and safety CSR disclosures following the airline accidents. Given the nature of the events we examine, we would anticipate a stronger focus on health and safety information provision following the disasters if the disclosure is aimed at addressing legitimacy concerns. As shown in Panel A of Table 3, the level of health and safety information provision is higher in the post-accident year in all four cases than it had been for either of the years preceding the crashes. However, while the increases in health and safety disclosures are relatively high (given the levels of disclosure in the pre-event periods) for the first three disasters, Air France’s increase following the Flight 447 event is more modest at only 0.26 pages. As noted in the table, this increase is actually considerably smaller than the increase of 0.83 pages from $\mathrm{Y}-2$ to $\mathrm{Y}-1$. In order to better assess the relative change in health and safety information provision in comparison to other CSR data, we show, in Panel B of Table 3, the percentage change in space following each accident relative to the average disclosure levels for the two years prior to the event. As documented in Panel B, the percentage increases in space are substantially more pronounced for health and safety information than for other CSR disclosures, and this holds in all four cases, although, once again, the change is much smaller following Air France's second incident than for any of the other disasters.

---------- Table 3 about here

Similar to our analysis of overall CSR disclosures, we next assess the changes in health and safety information across positive and negative classifications. As indicated in Table 4, in all four cases, while the affected companies increased the amount of space 
allocated to both positive and negative health and safety information, the increases were more pronounced with respect to the former. Indeed, with the exception of the AF 447 disaster, the increase in positive health and safety disclosures were more than double the amount of increase in negative information. In general, the analysis of health and safety disclosures supports the claim that the airline companies were using CSR disclosures as a response to the potential legitimacy threat arising from the disastrous crashes.

Table 4 about here

\subsection{Additional analysis - AF Flight 447}

While the CSR disclosure responses to the first three events are consistently in line with legitimation arguments, the lack of a similar pattern following Air France’s Flight 447 disaster is not. One possible explanation for the lack of response noted for the last event is that Air France may have used an alternative medium, its standalone CSR report, to respond to the 2009 event. The company was not issuing a standalone report at the time of the Concorde crash, but began doing so in 2003. As such, we extend the analysis for this event by accessing and reviewing the standalone CSR reports for the years surrounding the AF Flight 447 accident. Similar to the annual report analyses, we focus

on changes in total space, changes in positive disclosures, and changes in the provision of health and safety-related information. Table 5 presents the results of the standalone report examination, and, as highlighted in the table, we find decreases in disclosure for each of the metrics. And while the decreases are less pronounced than similar reductions in disclosure from $\mathrm{Y}-2$ to $\mathrm{Y}-1$, this pattern does not support a legitimation argument. 
The global financial crisis of the late 2000s might also potentially explain Air France’s decreases in CSR disclosure for 2009. At times of financial concerns, companies could choose to focus more specifically on economic issues. If this is the case, we would likewise expect other similar companies to reflect decreased CSR disclosure in their annual reports for 2009. We explore this potential explanation by examining the financial report CSR disclosures in 2008 and 2009 annual reports for nine other European airlines. ${ }^{8}$ While three of the companies did reduce the extent of CSR disclosures, only one, Flybe, was on a scale similar to the reduction noted for Air France. Further, the remaining six airlines exhibited increases in CSR disclosure, and on average across the nine companies, the extent of information changes was a positive 0.16 pages. These results would appear to suggest that Air France’s response was not merely a reaction to the global financial crisis. We discuss the contrary findings for AF Flight 447 in more detail in the conclusion section which follows.

\section{Conclusion}

In this study, we extend prior research into the use of CSR disclosure as a tool of legitimation by examining the changes in CSR information provided in the annual reports of airline companies suffering major catastrophic crashes in the $21^{\text {st }}$ century. Consistent with prior studies focusing primarily on environmental incidents and environmental disclosure (e.g., Cho, 2009; de Villiers and van Staden, 2011; Patten, 1992), we find, for three of the four disasters examined, evidence that the affected company appeared to change its CSR disclosure, presumably in an attempt to address legitimacy disclosures. Air France (in response to the Concorde crash in 2000), Singapore Airlines, and

\footnotetext{
${ }^{8}$ These are Aer Lingus, Aeroflot, British Airways, Easyjet, Flybe, Iberia Airlines, Lufthansa, Ryanair, and Scandinavian Airlines.
} 
Scandinavian Airlines all showed substantial increases in the space devoted to CSR information in annual reports released following the crashes. More specific analysis further indicates each of the firms exhibited substantially more disclosure of a positive nature following the disasters, and also allocated more space to disclosures related to health and safety issues. We interpret these changes as evidence of attempts at legitimation.

In contrast to the cases noted above, we find a different pattern of change in annual report CSR disclosure following the crash of Air France Flight 447 in 2009. Both total disclosure and the provision of items of a positive nature decreased in the report subsequent to the incident, and while the amount of space devoted to health and safety issues showed a small increase, it was not as large as a similar increase the prior year. We find similar patterns regarding changes in disclosure in Air France's standalone CSR reports for the years associated with the Flight 447 accident, and we document that, although 2009 was the height of the worldwide financial crisis of the late 2000s, other European airlines did not show a similar decrease in CSR disclosure. While the decrease in overall CSR disclosure for Air France could potentially be a function of the Flight 447 crash being the second disaster for the company in a relatively short period of time (leading to a potential concern that stakeholders would find CSR disclosure changes more disingenuous for a subsequent event), it would stand in contrast to Cho's (2009) findings of substantial increases in disclosure by the French oil company Total following a second major environmental disaster in the early 2000s. Instead, we believe Air France’s anomalous response may instead be a function of the company's refusal to take 
responsibility for the accident until the issuance of the formal investigative report in 2012.

In general, our evidence suggests that catastrophic events outside of the environmental domain also appear to induce at least some affected companies to use CSR disclosure to address potential legitimacy threats. As such, the findings add credence to concerns raised regarding the use of the disclosure. CSR reporting is often argued as a potentially powerful tool for increasing the transparency and accountability of organizations with respect to their social and environmental impacts (see, e.g. Gray and Bebbington, 2000; Medawar, 1976; Unerman et al., 2007). But Gray and Bebbington (2000, p. 16) further note that where CSR disclosure is voluntary, it will only reflect those aspects of performance that companies are willing to release, and accordingly, it can "only be a legitimation device and not an accountability mechanism.”

It is important to note that our investigation, like all studies, is subject to limitations. We acknowledge that we examine only four incidents, and as such, the findings are anecdotal in nature. Accordingly, the extent to which the actions we document would hold in other time frames or across other types of legitimacy-threatening situations cannot be assessed. Extending assessments of the corporate use of CSR disclosure to legitimacy-threatening events in other social arenas and across wider areas of time could provide additional insights on the practice. Further, particularly given the differential findings for the AF Flight 447 incident, qualitative investigations of the corporate response to airline disasters, and other social events with potential legitimacy impacts, could shed light on managerial perceptions of the response. 


\section{References}

Aerts, W. and Cormier, D. (2009), "Media legitimacy and corporate environmental communication”, Accounting, Organizations and Society, Vol. 34, pp. 1-27.

Ashforth, B. E., and Gibbs, B. W. (1990), “The double-edge of legitimization”, Organization Science, Vol. 1, No. 1, pp. 177-194.

Bailey, J. (2004), "Emerging from a crisis unscathed”, [www] The Business Times (Singapore): Online Edition, 24 February, available from: http://www.businesstimes.com.sg/singapore [accessed 01 September 2009].

Bunting, M. (2000), "Comment: excessive media coverage of the Concorde exposes our voyeurism”, [www], The Guardian, Special Report: the Concorde Crash, 27 July 2000, available from: http://www.guardian.co.uk/uk/2000/ jul/27/ concorde.world1 [accessed 15 July 2009].

Cho, C. H. (2009), "Legitimation strategies used in response to environmental disaster: a French case study of Total SA's Erika and AZF incidents”, European Accounting Review, Vol. 18, No. 1, pp. 33-62.

Cho, C. H. and Patten, D. M. (2007). "The role of environmental disclosures as tools of legitimacy: a research note.” Accounting, Organizations and Society, Vol. 32, Nos. 7/8, pp. 639-647.

Coetzee, C. M. and van Staden, C. J. (2011), "Disclosure responses to mining accidents: South African evidence”, Accounting Forum, Vol. 35, No. 4, pp. 232-246.

De Villiers, C. and van Staden, C.J. (2011), "Where firms choose to disclose voluntary environmental information”, Journal of Accounting and Public Policy, Vol. 30, pp. 504-525.

Deegan, C. and Rankin, M. (1996), "Do Australian companies report environmental news objectively? An analysis of environmental disclosures by firms prosecuted successfully by the environmental protection authority”, Accounting, Auditing \& Accountability Journal, Vol. 9, No. 2, pp. 50-67.

Deegan, C., Rankin, M., and Voght, P. (2000), “Firms' disclosure reactions to major social incidents: Australian evidence”, Accounting Forum, Vol. 24, No. 1, pp. 101130.

Deegan, C., Rankin, M., and Tobin, J. (2002), “An examination of the corporate social and environmental disclosures of BHP from 1983-1997”, Accounting, Auditing \& Accountability Journal, Vol. 15, No. 3, pp. 312-343.

Dowling, J. and Pfeffer J. (1975), “Organizational legitimacy: social values and organizational behaviour”, Pacific Sociological Review, Vol. 18, No. 1, pp. 122-136.

Ernst and Ernst (1978), Social Responsibility Disclosure: 1978 Survey, Ernst and Ernst, Cleveland, $\mathrm{OH}$.

Gero, D. (2006), Aviation disasters: the world's major civil airliner crashes since 1950, $4^{\text {th }}$ Ed., Haynes Publishing, Sparkford.

Gray, R. H. and Bebbington, J. (2000). "Environmental accounting, managerialism and sustainability: is the planet safe in the hands of business and accounting?” Advances in Environmental Accounting and Management, Vol. 1, pp. 1-44.

Gray, R., Kouhy, R., and Lavers, S. (1995), "Methodological themes: constructing a research database of social and environmental reporting by UK companies”, Accounting, Auditing \& Accountability Journal, Vol. 8, No. 2, pp. 78-101. 
GRI (Global Reporting Initiative) (2002), Sustainability Reporting Guidelines, GRI, Boston, MA.

GRI (Global Reporting Initiative) (2006), Sustainability Reporting Guidelines, V.3.0, GRI, Amsterdam.

Grossman, D. (2005), “Check your travel superstitions, or carry them on?” USA Today, 31 October.

Guthrie, J. E. and Parker, L. D. (1989), “Corporate social reporting: a rebuttal of legitimacy theory”, Accounting and Business Research, Vol. 9, No. 76, pp. 343-352.

Hackston, D. and Milne, M. J. (1996), "Some determinants of social and environmental disclosures in New Zealand companies”, Accounting, Auditing \& Accountability Journal, Vol. 9, No. 1, pp. 77-108.

Islam, M.A. and Deegan, C. (2010), "Media pressures and corporate disclosure of social responsibility performance information: a study of two global clothing and sports retail companies”, Accounting and Business Research, Vol. 40, No. 2, pp. 131-148.

Knight, R. F. and Pretty, D. J. (1996), “The impact of catastrophes on shareholder value”, The Oxford executive research briefings, University of Oxford, Oxford.

Kotonen, U. (2009), "Formal corporate social responsibility reporting in Finnish listed companies”, Journal of Applied Accounting Research, Vol. 10, No. 3, pp. 176-207.

Lindblom, C. K. (1993), "The implications of organisational legitimacy for corporate social performance and disclosure”, paper presented at the Critical Perspectives on Accounting Conference, New York.

Lombard, M., Snyder-Duch, J. and Bracken, C.C. (2002), "Content analysis in mass communication: assessment and reporting of intercoder reliability”, Human Communication Research, Vol. 28, pp. 587-604.

Mahadeo, J.D., Oogarah-Hanuman, V. and Soobaroyen, T. (2011), “Changes in social and environmental reporting practices in an emerging economy (2004-2007): exploring the relevance of stakeholder and legitimacy theories”, Accounting Forum, Vol. 35, pp. 158-175.

Medawar, C. (1976). “The social audit: a political view.” Accounting, Organizations and Society, Vol.1, No. 4, pp. 389-394.

O’Dwyer, B. (2003), “The ponderous evolution of corporate environmental reporting in Ireland. Recent evidence from publicly listed companies”, Corporate Social Responsibility and Environmental Management, Vol. 10, pp. 91-100.

Parsons, T. (1960), Structure and process in modern societies, Free Press, New York, NY.

Patten, D. (1992), "Intra-industry environmental disclosures in response to the Alaskan oil spill: a note on legitimacy theory”, Accounting, Organizations and Society, Vol. 17, No. 5, pp. 471-475.

Perrin, A. (2000), “What went wrong?”, [www], Australian, 16 December, available from: http://www.theaustralian.news.com.au [accessed 20 August 2009].

Perrow, C. (1970), Organizational analysis: a sociological view, Wandsworth, Belmont, CA.

Pesci, C. and Costa, E. (2014), "Content analysis of social and environmental reports of Italian Cooperative Banks: Methodological Issues”, Social and Environmental Accountability Journal, Vol. 34, No. 3, pp. 157-171.

Ross, N.and Tweedie, N. (2012), Air France Flight 447: 'Damn it, we're going to crash', [www], The Telegraph, 28 April, available from: 
http://www.telegraph.co.uk/technology/9231855/Air-France-Flight-447-Damn-itwere-going-to-crash.html [accessed 17 November 2013]

Savage, A., Cataldo, A. J., and Rowlands, J. (2000), “A multi-case investigation of environmental legitimation in annual reports", Advances in Environmental Accounting and Management, Vol. 1, pp. 45-81.

Sen, M., Mukherjee, K. and Pattanayak, J.K. (2011), "Corporate environmental disclosure practices in India”, Journal of Applied Accounting Research, Vol. 12, No. 2, pp. 139-156.

Slack, R. and Shrives, P. (2008), "Social disclosure and legitimacy in Premier League football clubs: the first ten years”, Journal of Applied Accounting Research, Vol. 9, No. 1, pp. 17-28.

Unerman, J. (2000), "Methodological issues: reflections on quantification in corporate social reporting content analysis”, Accounting, Auditing \& Accountability Journal, Vol. 13, No. 5, pp. 667-680.

Unerman, J., J. Bebbington, and B. O’Dwyer. (2007). Introduction to sustainability accounting and accountability. In Unerman, J., Bebbington, J. and O'Dwyer, B. (Eds.), Sustainability Accounting and Accountability, Oxon, UK: Routledge, pp. 1-16.

Walden, W. D. and Schwartz, B. (1997), "Environmental disclosures and public policy", Journal of Accounting and Public Policy, Vol. 16, pp. 125-154.

Weber, M. (1978), Economy and society, University of California Press, Berkeley, CA.

Woodward, D. G., Paterson, C., and Woodward, T. (2008), "Levels of corporate disclosure following three major UK transport accidents", paper presented in the Critical Perspectives on Accounting conference, New York, 24-26 April.

Zyglidopoulos, S. C. (2001), "The impact of accidents on firms' reputation for social performance”, Business and Society, Vol. 40, No. 4, pp. 416-441. 
Table 1 - Pages of annual report disclosure.

\begin{tabular}{|c|c|c|c|c|c|c|}
\hline \multirow[b]{2}{*}{ Event } & \multirow[b]{2}{*}{$\begin{array}{l}\text { Accident } \\
\text { Disclosure }\end{array}$} & \multicolumn{3}{|c|}{$\begin{array}{l}\text { Total CSR } \\
\text { Disclosure }\end{array}$} & \multirow[b]{2}{*}{$\begin{array}{l}\text { Change } \\
\text { Prior }\end{array}$} & \multirow[b]{2}{*}{$\begin{array}{c}\text { Change } \\
\text { Post }\end{array}$} \\
\hline & & $\mathrm{Y}-2$ & $\mathrm{Y}-1$ & $\mathrm{Y} 1$ & & \\
\hline AF Flight 4590 & 0.25 & 8.44 & 10.55 & 14.66 & 2.11 & 4.11 \\
\hline SIA Flight 006 & 0.43 & 4.91 & 6.21 & 12.13 & 1.30 & 5.92 \\
\hline SAS Flight 686 & 0.46 & 12.31 & 11.65 & 25.44 & -0.66 & 13.79 \\
\hline AF Flight 447 & 0.17 & 23.04 & 23.82 & 23.62 & 0.78 & -0.20 \\
\hline
\end{tabular}


Table 2 - Pages of annual report disclosure - CSR sub-components.

Panel A - Positive CSR Disclosures

\begin{tabular}{lccccc} 
Event & Y-2 & Y-1 & Y1 & $\begin{array}{c}\text { Change } \\
\text { Prior }\end{array}$ & $\begin{array}{c}\text { Change } \\
\text { Post }\end{array}$ \\
AF Flight 4590 & 5.75 & 7.14 & 13.21 & 1.39 & 6.07 \\
SIA Flight 006 & 4.55 & 5.40 & 10.84 & 0.85 & 5.34 \\
SAS Flight 686 & 7.99 & 8.34 & 15.19 & 0.35 & 6.85 \\
AF Flight 447 & 14.21 & 16.11 & 8.99 & 1.90 & -5.22 \\
\hline
\end{tabular}

Panel B - Negative CSR Disclosures

\begin{tabular}{lccccc} 
Event & Y-2 & Y-1 & Y1 & $\begin{array}{c}\text { Change } \\
\text { Prior }\end{array}$ & $\begin{array}{c}\text { Change } \\
\text { Post }\end{array}$ \\
AF Flight 4590 & 0.63 & 0.70 & 0.87 & 0.07 & 0.17 \\
SIA Flight 006 & 0.28 & 0.37 & 0.79 & 0.09 & 0.42 \\
SAS Flight 686 & 1.52 & 1.11 & 3.37 & -0.41 & 2.26 \\
AF Flight 447 & 3.07 & 4.18 & 5.05 & 1.11 & 0.93 \\
\hline
\end{tabular}


Table 3 - Health and Safety CSR Disclosures

Panel A - Health and Safety CSR Disclosures over Time

Event

$\mathrm{Y}-2$

$\mathrm{Y}-1$

$\mathrm{Y} 1$

Change Change

AF Flight 4590

1.19

0.32

1.60

$-0.87$

1.28

SIA Flight 006

0.32

0.64

2.12

0.32

1.48

SAS Flight 686

1.80

3.02

5.92

$1.22 \quad 2.90$

AF Flight 447

1.42

2.25

2.51

0.83

0.26

Panel B - Percentage Change in Disclosure versus Other CSR Areas ${ }^{\mathrm{a}}$

Event

AF Flight 4590

SIA Flight 006

SAS Flight 686

AF Flight 447

\section{Health and Safety}

Disclosures

$$
+112.0 \%
$$$$
+341.7 \%
$$

$+145.6 \%$

$+36.8 \%$
All Other CSR

Disclosures

$+49.7 \%$

$+74.1 \%$

$+99.9 \%$

$+6.2 \%$

a Percentage change in disclosure is computed as (disclosure in $\mathrm{Y} 1$ minus average pages of disclosure for $\mathrm{Y}-2$ and $\mathrm{Y}-1$ )/average pages of disclosure for $\mathrm{Y}-2$ and $\mathrm{Y}-1$. 
Table 4 - Health and Safety CSR Disclosures - CSR sub-components.

Panel A - Positive Health and Safety Disclosures

$\begin{array}{lccccc}\text { Event } & \text { Y-2 } & \text { Y-1 } & \text { Y1 } & \begin{array}{c}\text { Change } \\ \text { Prior }\end{array} & \begin{array}{c}\text { Change } \\ \text { Post }\end{array} \\ \text { AF Flight 4590 } & 1.07 & 0.25 & 1.31 & -0.82 & 1.06 \\ \text { SIA Flight 006 } & 0.28 & 0.54 & 1.58 & 0.26 & 1.04 \\ \text { SAS Flight 686 } & 1.00 & 2.50 & 4.28 & 1.50 & 1.78 \\ \text { AF Flight 447 } & 1.42 & 2.13 & 2.24 & 0.71 & 0.21\end{array}$

Panel B - Negative Health and Safety Disclosures

$\begin{array}{llllll}\text { Event } & \mathrm{Y}-2 & \mathrm{Y}-1 & \mathrm{Y} 1 & \text { Change } & \text { Change } \\ & & & \text { Prior } & \text { Post }\end{array}$

\begin{tabular}{lccccc} 
AF Flight 4590 & 0.07 & 0 & 0.29 & -0.07 & 0.29 \\
SIA Flight 006 & 0.04 & 0.06 & 0.54 & 0.02 & 0.48 \\
SAS Flight 686 & 0.33 & 0.20 & 1.13 & -0.13 & 0.93 \\
AF Flight 447 & 0 & 0 & 0.17 & 0 & 0.17 \\
\hline
\end{tabular}


Table 5 - Pages of Air France standalone CSR report disclosure - AF Flight 447

\begin{tabular}{|c|c|c|c|c|c|}
\hline Disclosure Area & $\mathrm{Y}-2$ & Y-1 & Y1 & $\begin{array}{l}\text { Change } \\
\text { Prior }\end{array}$ & $\begin{array}{c}\text { Change } \\
\text { Post }\end{array}$ \\
\hline Total & 43.97 & 38.28 & 35.75 & -4.69 & -2.53 \\
\hline Positive & 40.45 & 34.75 & 29.98 & -5.70 & -4.77 \\
\hline Health \& Safety & 3.31 & 2.64 & 2.47 & -0.66 & -0.17 \\
\hline
\end{tabular}




\section{Appendix A - CSR disclosure categories}

A. Health and Safety

1. Health and safety at the workplace

- Any reference/compliance to health and safety law

- Information to employees, training on health and safety

- Accidents, with reference to the employees

- Receiving safety awards

- Conducting research to improve work safety

- Standard injury, lost day and absentee rates and number of work-related fatalities

- Description of policies or programmes on specific diseases (e.g. HIV/AIDS)

- Providing information on industrial action related to health and safety

- Incidents of air rage

- Reference to aircraft age when not linked with noise, emissions, or energy

2. Health and safety at the marketplace

- Health and safety of the product

- Accidents, with reference to the customers

- Description of policy for preserving customer health and safety during use of products and services

- Monitoring systems and results of monitoring of these policies

3. Health and safety of community

- Description of policies to manage health and safety impacts on communities affected by organisational activities

- Extent to which these policies are visibly stated and applied

- Monitoring systems and results of monitoring these policies

- Disclosures regarding noise: infringements, fines, plane night movements

- Reference to aircraft age when linked with noise

- Reference to Continuous Descent Approach (CDA) and departures on track

4. Health and safety - other

- Other general issues regarding health and safety

B. Marketplace

5. Consumers

- Consumer complaints and related awards

- Congestion, when linked with customer delays but not additional fuel

- Specific customer relations (over and beyond 'our duty to the customer')

- Provision for disabled, aged, etc. customers

- Provision for difficult to reach customers

- Training employees in customer service

- Consumer privacy policy, procedures/management systems and compliance mechanisms 
- Expansions in the route network (but NOT information on their first class offers or dietary offers/ other 'new services')

- Consultation with consumers (frequency, information generated, use of information)

6. Creditors

- Specific creditor relations

- Policies with regards to creditors

- Consultation with creditors (frequency, information generated, use of information)

C. Workplace

7. Employee and pension data

- Statutory average numbers employed by category and wages (including pension and social security costs) and geographic area

- Statutory numerical analysis of employees $>£ 30,000$

- Statutory disclosures of directors' emoluments (but not their bios)

- Thanks to employees

- Donations ditto by/ through employees

- Statutory particulars for commitments for pensions, whether or not provided

- Pensions and benefits beyond coverage of statutory material

- Any other employee information, not covered in the below categories, including reference to social audits

8. Equal opportunities and employee development - training

- Training above health and safety

- Training employees in customer service

- Training employees in environmental issues

- Average hours of training per year per employee by category of employee

- General employee development

- Description of equal opportunity policies or programmes (racial, sexual equality, parental leave, etc.) and policies on harassment and bullying

- Statutory reference to the employment of disabled persons (including retraining)

- Monitoring systems to ensure compliance - results of monitoring

- Indicators of diversity as culturally appropriate (e.g. female/male ration in senior management and corporate governance bodies)

- Policies/references to bribery and corruption in the marketplace

9. Human rights

- Policies, guidelines, corporate structure and procedures to deal with all aspects of human rights relevant to operations, including immigration/ asylum seekers' cases

- Consideration of human rights within the supply chain and on selection of suppliers/ contractors, excluding collective bargaining/ references to industrial relations

- Description of policy excluding child labour as defined by the ILO Convention 138 
- Description of policy to prevent forced and compulsory labour and extent to which this policy is visibly stated and applied

- Any reference to policies regarding prevention of sexual or other harassment

- Monitoring systems of the above policies and results of monitoring

10. Consultation with employees

- Statutory action with respect to informing employees on matters of concern, consulting employees or representatives, encouraging (and engaging in) employee participation

- Statutory increasing employee financial and economic awareness

- Reference to industrial relations, strike action or talks with unions

- Employee opinion surveys and individual advice and counselling

11. Share ownership

- Statutory encouragement and participation of employees in share schemes, profit sharing, ESOPs, where employees does not mean directors

- Schemes/ reference must be to employees (exclude if reference is to executive or directors only)

- Loans for this purpose but not directors

- SAYE options

D. Community

12. Community involvement

- Any reference to community and/ or social involvement outside the labour force

- Sponsoring/ funding schools, arts, sports, medical research, development of local communities/ industries and activities

- Particular reference to bribery and corruption in communities

- Consultation with community (frequency, information generated, use of information)

- Excluding charities

13. Charities

- Statutory donations in monetary form or in kind to registered charities within the Company Act

- Donations ditto by/ through employees (e.g. GAYE schemes)

- Statutory references and amounts of political donations (as they fall within the same Company Act requirement)

E. Environment

14. Environmental pollution

- Air, Water (including consumption), emissions, visual quality, fuel jettison and pollution plus any attempt to identify, improve or prevent pollution

- Environmental audits and charges pertaining to emissions, pollution

- Conservation of natural resources, waste and recycling including improvements in products 
- Statements indicating that the company's operations are in compliance with environmental laws and regulations; recognition of the need to comply with society standards and regulations

- Involvements with schemes (E.g. Business in the Environment, Business in Community, ACBE, etc.)

- Except in so far as its part of the business (e.g. waste disposal or environmental technology)

- Environmental Awards won or external praise for environmental work

- Reference to aircraft age when linked to emissions

15. Energy

- Energy saving and conservation

- Fuel (i.e. oil, gas) and electricity consumption, fuel jettison and charges pertaining to energy

- Use/ development/ exploration of new sources, efficiency, insulation, etc.

- Except in so far as it is part of the business (e.g. oil exploration companies)

- Utilising waste materials for energy production

- Disclosing energy savings resulting from product recycling

- Discussing the company's efforts to reduce energy consumption

- Disclosing increased energy efficiency of products

- Receiving awards for energy conservation programmes

- Disclosing the company's energy policies

- Reference to aircraft age when linked to energy savings

- Reference to congestion when linked to additional fuel

16. Aesthetics

- Designing facilities harmonious with the environment

- Contributions in the terms of case or art/sculptures to beautify the environment

- Restoring historical buildings/structures

- General environmental activities linked with tourism

17. Environment - other

- Undertaking environmental impact studies to monitor the company's impact on the environment, conducting reviews of performance, employing specialist consultants

- Wildlife conservation, environmental newsletters and biodiversity

- Training employees in environmental issues

F. Other

18. Value added statement

- Any reference to the creation and distribution of value added

- Any statement headed valued added or added value

- Any statement with 'distribution' to employees and state (not including shareholders) 
19. Other CSR information

- General CSR objectives and mission statements; ethics; political statements; value of company to nation, economy; assurance statements; general references to stakeholders and competitors and to sustainability 